\title{
Price Transmission in International Crude Palm Oil Markets: The Effects of Export Tax of Indonesia
}

\author{
Immanuel Manurung \\ The Directorate of Export of \\ Agricultural and Forestry Products \\ Ministry of Trade \\ Indonesia \\ immanuel.alfonsus@yahoo.co.id
}

\author{
Bernhard Bruemmer \\ Department of Agricultural Economics and \\ Rural Development \\ University of Goettingen \\ Germany \\ bbruemm@gwdg.de
}

\author{
Thomas Kopp \\ Department of Agricultural Economics and \\ Rural Development \\ University of Goettingen \\ Germany \\ thomas.kopp@agr.uni-goettingen.de
}

\begin{abstract}
Over the past decade, there have been fluctuations in the global price of CPO. These variations in global CPO price are likely to affect the local CPO price as well. To overcome this, the Indonesian government has implemented an export tax on CPO in order to maintain stability in the business of the CPO producers. The aims of this research are to assess the market integration and the price transmission between the international CPO market and the domestic CPO market of Indonesia as well as the effects of the Indonesian export tax on the domestic and on the international prices. The analysis uses $\mathbf{5 9 2}$ weekly prices from January 2005 to May 2017 and estimation of Error Correction Model as an analysis method. The results of analysis show that the domestic CPO market of Indonesia is integrated with the international market. The domestic CPO market in Indonesia responds to price fluctuations in international market. In addition, although the imposition of the export tax of CPO in Indonesia slightly reduces instability of the domestic CPO price, the overall influence is still small. It can be inferred that the policy is effective to increase government revenue as a fiscal instrument at the expanse of oil palm farmers and producers of CPO. In practice, even though the policy maker has attempted to reduce the dependency of the Indonesian CPO producers on the world market by creating a demand market, but the Indonesian government still need to optimize the policy under the new format of the export tax of CPO.
\end{abstract}

Keywords-CPO, ECM, Export Tax, Market Integration, Price Transmission

\section{INTRODUCTION}

The economic potential of CPO commodity in Indonesia has a huge impact by providing around 16 million employments within the agribusiness palm oil system. Indonesia is the biggest producer and exporter of CPO in the world, followed by Malaysia. As the largest CPO producer in the world, Indonesia should have control over the price and quantity of CPO. Over the past decade, there have been fluctuations in the global price of CPO leading to a decrease of 0.8 per cent in prices. CPO's world price reached 1033 USD/Ton in 2011 and declined to about $750 \mathrm{USD} / \mathrm{Ton}$ in 2014 (Immanuel et al. 2016).

These variations in global CPO price are likely to affect the local CPO price as well. As the price of the world CPO fluctuates, Indonesia lacks alternative markets for its local production of CPO. This has resulted in an unstable in the tax revenue of CPO in Indonesia. To solve this, Goverrnment have implemented a Indonesia's export tax on CPO in order to maintain stability in the income of the $\mathrm{CPO}$ producers. Due to these conditions, this study seeks to ascertain how policies implemented by the Indonesian government affect the price transmission of CPO on the domestic CPO market and the international CPO market.

\section{A. Export Tax on Crude Palm Oil}

Indonesian palm oil exports apply in the form of Fruit Fresh Bunch, Crude Palm oil, and its derivative products. K.P.E. Intan et al. (2008) highlighted the dynamic of export tax during period of 2004-2006 from the point of view of farmers; the export tax of CPO reduces their income of farmers due to the price of fruit fresh bunch. In order to increase revenue from fiscal instrument, government is not willing to abolish the export tax. Obado et al (2009) investigated the impact of the CPO export tax on Indonesian CPO industry and particularly focuses on domestic price, investment, production, consumption, export, employment, added-value, cooking oil price, government revenue, producer surplus and consumer surplus. Sulistyanto and Akyuwen (2011) investigated the impact of export tax and inferred that government policy does not have optimum impact to support the export of CPO of Indonesia.

\section{B. Price Volatility on Agricultural Commodities}

Palm oil is inelastic in supply as well as the price of CPO in both, domestic and global markets. This therefore has affected by business cycle and the seasonal volatility. In line with that issue, Drajad (2007) in Rachman (2012) revealed that the period of the decreasing of the CPO price occurs from May until July, while the turning point resulting to the increase in price is in December or January. Marshalian (1981) in Khotimah (2013) depicted the goal of price stabilization as a way to prevent the prices from having a high volatility. Meanwhile, in a short period of time price might be unstable due to the changing of supply and demand in the product market.

\section{Market Integration and Price Transmission in Agricultural Markets}

The concept of market integration refers to the existence of price co-movement between markets imposed by the law of one price (LOP). This theory supports the capture of how market works. Hafizah (2011) emphasized that was cointegration between CPO prices in three different markets: Rotterdam, Malaysia, and Indonesia. This study showed that the Indonesia government has no bargaining power to control 
both, domestic and global prices. Fadila (2014) generated results show co-integration between all variable prices in the long run period, however in the short period, only crude oil and CPO demonstrated two ways causal relationship.

\section{METHODOLOGY}

\section{A. Data Description}

This study uses secondary time series data. The palm oil and its fraction product has the Harmonized System (HS) code 1511 and is divided into Crude Palm Oil (HS code: 151110) and Refined Palm Oil but no chemically modified (HS code: 151190).

\section{B. Data Processing and Analysis Method}

\section{1) Testing for Unit Roots}

As the situation of the variable of the export tax of CPO has some zero tariff of export tax, there is the strategy of adding 1 to the dependent variable before the logarithm is taken which is for example followed by Agostino et al (2010) in Kopp et al (2014).

$$
\Delta \mathrm{Yt}=\alpha 0+\alpha 1 \mathrm{~T}+\delta \mathrm{tY} \mathrm{t}-\mathrm{i}+\Sigma \beta \mathrm{i} \Delta \mathrm{Yt}-\mathrm{i}+\varepsilon \mathrm{t}
$$

\section{2) Cointegration Test}

In particular, testing for co-integration with more than two series would be able by applied Johansen's method. Supposed the vector autoregression (VAR) of order $\mathrm{p}$ :

$$
\mathrm{Yt}=\mathrm{A} 1 \mathrm{Yt}-1+\ldots+\mathrm{ApYt}-\mathrm{p}+\mathrm{B} \mathrm{Xt}+\varepsilon \mathrm{t}
$$

Where Yt is a k vector of non-stationary $\mathrm{I}(1)$ variables, $\mathrm{Xt}$ is a $\mathrm{d}$ vector of deterministic variables, and $\varepsilon t$ is a vector of innovations. The VAR equation above can be written as:

$$
\begin{aligned}
& \text { p-1 } \\
& \Delta \mathrm{Yt}=\Pi \mathrm{Yt}-1+\sum \Gamma \mathrm{i} \Delta \mathrm{Yt}-\mathrm{i}+\mathrm{B} \mathrm{Xt}+\varepsilon \mathrm{t} \\
& \mathrm{i}=1 \\
& \mathbf{i}=\mathbf{j} \quad \mathbf{j}=\mathbf{i}+1
\end{aligned}
$$

\section{3) Error Correction Model}

This analysis uses the Johansen Maximum Likelihood Error Correction Model with the specification of Error Correction Model and long run model (ECTt-1) as written below:

$$
\mathrm{n} n
$$

$$
\begin{gathered}
\Delta \mathrm{Yt}=\boldsymbol{\beta} \mathbf{0}+\sum \beta \mathrm{i} \Delta \mathrm{Yt}-\mathrm{i} \boldsymbol{\delta} \mathbf{i} \Delta \mathrm{Xt}-\mathrm{i}+\varphi \mathrm{Zt}-\mathrm{i}+\mu \mathrm{t} \\
\mathrm{i}=\mathbf{1} \quad \mathbf{i}=\mathbf{0}
\end{gathered}
$$

\begin{tabular}{|c|c|c|c|c|c|c|}
\hline \multirow[t]{2}{*}{ Year } & \multicolumn{2}{|c|}{$\begin{array}{l}\text { Averages Price } \\
\text { (USD/Ton) }\end{array}$} & \multicolumn{2}{|c|}{$\begin{array}{c}\text { Standard Deviation } \\
(\%)\end{array}$} & \multicolumn{2}{|c|}{$\begin{array}{l}\text { Coefficient of } \\
\text { Variation (\%) }\end{array}$} \\
\hline & Indonesia & Rotterdam & Indonesia & Rotterdam & Indonesia & Rotterdam \\
\hline 2005 & 412.4 & 420.0 & 19.5 & 17.0 & 4.72 & 4.05 \\
\hline 2006 & 459.1 & 474.5 & 56.5 & 50.4 & 12.31 & 10.62 \\
\hline 2007 & 779.3 & 785.4 & 110.6 & 121.0 & 14.19 & 15.41 \\
\hline 2008 & 839.2 & 946.1 & 241.0 & 288.4 & 28.72 & 30.49 \\
\hline 2009 & 657.7 & 679.2 & 89.2 & 79.0 & 13.56 & 11.63 \\
\hline 2010 & 863.8 & 903.7 & 122.7 & 143.2 & 14.21 & 15.85 \\
\hline 2011 & 1011.5 & 1120.3 & 70.7 & 91.0 & 6.99 & 8.12 \\
\hline 2012 & 912.3 & 995.7 & 122.9 & 130.3 & 13.47 & 13.09 \\
\hline 2013 & 798.3 & 853.8 & 31.0 & 30.7 & 3.88 & 3.60 \\
\hline 2014 & 754.3 & 816.7 & 93.9 & 92.4 & 12.45 & 11.32 \\
\hline 2015 & 561.4 & 619.4 & 77.5 & 56.8 & 13.80 & 9.16 \\
\hline 2016 & 641.8 & 704.0 & 73.3 & 65.8 & 11.42 & 9.34 \\
\hline 2017* & 699.5 & 757.9 & 55.9 & 50.1 & 7.99 & 6.61 \\
\hline $\begin{array}{c}\text { Aver } \\
\text { age }\end{array}$ & 722.3 & 775.1 & 89.6 & 93.5 & 12.1 & 11.5 \\
\hline
\end{tabular}

$$
\mathrm{Zt}-\mathrm{I}=\mathrm{ECTt}-1=\mathrm{Yt}-1-\beta \mathbf{0}-\beta \mathbf{X} \mathrm{t}-1
$$

\section{RESULTS AND DISCUSSION}

\section{A. The Volatilities of CPO Prices}

The volatility of the domestic price of the CPO from Indonesia was higher than the volatility of the global price.
The fluctuation of the world economy in 2008 caused the international and domestic prices to reach the highest volatility by 28.72 per cent and 30.49 per cent respectively.

TABLE I. THE PRICE VOLATILITIES OF INTERNATIONAL AND DOMESTIC OF CPO PRODUCT (\%)

Source: Author's calculation

\section{B. CPO Price Transmission and Market Integration}

\section{1) Unit Root Test}

Based on the table below, the results of the ADF unit root test show the prices series for all variables to be stationary at the first difference, $\boldsymbol{I}(1)$.

TABLE II. UNIT ROOT TEST RESULT IN LEVEL

\begin{tabular}{|c|c|c|c|c|}
\hline \multirow{2}{*}{ Variable } & \multicolumn{4}{|c|}{ Level } \\
\cline { 2 - 5 } & \multicolumn{2}{|c|}{ With constant } & \multicolumn{2}{c|}{$\begin{array}{c}\text { With constant } \\
\text { and trend }\end{array}$} \\
\cline { 2 - 5 } & $\begin{array}{c}\text { ADF } \\
\text { Value }\end{array}$ & $\begin{array}{c}\text { P- } \\
\text { value }\end{array}$ & $\begin{array}{c}\text { ADF } \\
\text { Value }\end{array}$ & $\begin{array}{c}\text { P- } \\
\text { value }\end{array}$ \\
\hline Ln CPO Domestic & -2.20 & 0.21 & -2.02 & 0.59 \\
\hline Ln CPO Rotterdam & -2.14 & 0.23 & -1.89 & 0.66 \\
\hline Ln Crude Oil & -2.14 & 0.23 & -2.31 & 0.43 \\
\hline Ln Export Tax & -2.73 & 0.07 & -2.81 & 0.19 \\
\hline
\end{tabular}

All regressions in first difference reject the null of absence of unit roots at $1 \%$ confidence level. Therefore, it is to be concluded that all variable are stationary and valid to use. 
TABLE III. UNIT ROOT TEST RESULT IN $1^{\text {ST }}$ DIFFERENCE

\begin{tabular}{|c|c|c|c|c|}
\hline \multirow{2}{*}{ Variable } & \multicolumn{4}{|c|}{ First Difference } \\
\cline { 2 - 5 } & \multicolumn{2}{|c|}{ With constant } & \multicolumn{2}{c|}{$\begin{array}{c}\text { With constant and } \\
\text { trend }\end{array}$} \\
\cline { 2 - 5 } & $\begin{array}{c}\text { ADF } \\
\text { Value }\end{array}$ & $\begin{array}{c}\text { P- } \\
\text { value }\end{array}$ & $\begin{array}{c}\text { ADF } \\
\text { Value }\end{array}$ & P-value \\
\hline Ln CPO Domestic & -24.38 & 0.00 & -2.02 & 0.00 \\
\hline Ln CPO Rotterdam & -26.48 & 0.00 & -1.89 & 0.00 \\
\hline Ln Crude Oil & -27.11 & 0.00 & -2.31 & 0.00 \\
\hline Ln Export Tax & -25.36 & 0.00 & -25.34 & 0.00 \\
\hline
\end{tabular}

\section{2) Cointegration Analysis and Error Correction Model}

The table below shows the result from the Johansen test implying the existence of cointegration between world and domestic market of CPO product.

TABLE IV. RESULT OF JOHANSEN TEST (CRITERION BIC)

\begin{tabular}{|c|c|c|}
\hline & Trace Statistic & P-value \\
\hline 0 & 63.57 & 0.014 \\
\hline 1 & 15.95 & 0.904 \\
\hline 2 & 4.99 & 0.901 \\
\hline
\end{tabular}

For the next step as the subsequent process for proving that there is one cointegrating vector between all prices, it is necessary to observe the extent of their relationship. Nonetheless, the result of checking the stability analysis is that the model contains the presence of structural changes. The output of the Chow test is presented inside the table V.

TABLE V. THE RESULT OF CHOW TEST

\begin{tabular}{|c|c|c|}
\hline Dummy Series Plot & F-Test & P-value \\
\hline drotw4jan15 & 2.55 & 0.019 \\
\hline drotw4sept15 & 3.22 & 0.007 \\
\hline
\end{tabular}

The Chow test rejects the null hypothesis of no structural change, thus there is a need to apply dummy variable in the standard VECM to obtain a more precise analysis. Besides that, the model has a problem of outliers (spikes) in several series, thus more dummy variables are added in particular for the residual of export tax of CPO in the short run period to cope with the outliers.

According to the output (Table VI), in the long run, if the Rotterdam CPO price increases by 1 per cent, the domestic price of Indonesia's CPO increases by 0.93 per cent on average. Beside that, there is an integrated market between both prices that will influence the long run equilibrium price. Hence, the changing price from CPO Rotterdam might be transmitted to the price of $\mathrm{CPO}$ in the domestic market in Indonesia. Interpreting the coefficient of the export tax of CPO it can be said that there is a reduction of the domestic price of CPO Indonesia by 0.009 per cent in the long run period if the export tax of CPO increases by 1 per cent. The expected sign appearing in the model confirms the hypothesis according to which an influence of the CPO price of Rotterdam market on the domestic price of CPO of Indonesia in the same direction is to be expected. Whereas the export tax is expected reduce the domestic price of CPO Indonesia.

TABLE VI.THE ERROR CORRECTION MODEL FOR THE CPO PRICES

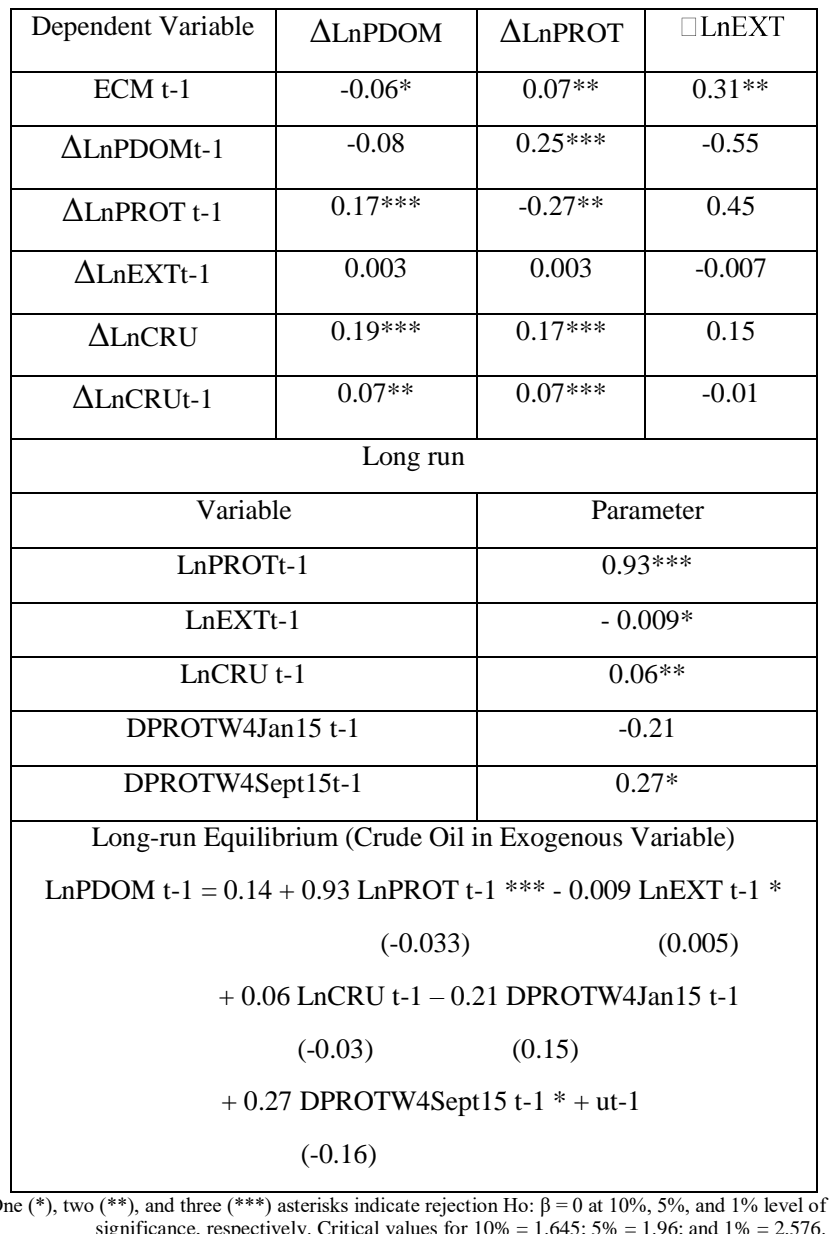

The finding above meets the main purpose of export tax on palm oil products in Indonesia which is basically intends to save potential short supply of raw material for the domestic Industry. Moreover, this policy ensures the price stability by changing the composition of the product to be exported more to the downstream industry.

The relationship between crude oil and the domestic price of CPO Indonesia has a positive sign and is statistically significant at 5 per cent and 10 per cent significance level. It means the price of international crude oil will influence the development of the domestic price of CPO Indonesia in the long run period. This is the indirect consequence because biodiesel produced from $\mathrm{CPO}$ is the substitute product of crude oil, so the higher price of crude oil will increase the CPO Rotterdam price.

The connection between price of crude oil and biodiesel is really fit the new current issue of renewable energy which Indonesian government starts to develop the usage of palm oil for boosting the B20-B30 program nationwide. In the future, the supply of palm oil might be absorbed not only for food, feed and cosmetic products, but also mainly for renewable energy sector. 


\section{3) The Short Run Effect of Shock of Export Tax to CPO Prices}

Impulse Response Functions are interpreted as the effect that a shock has on an observable variable through time. The horizontal axis represents the period in weeks, while the vertical axis shows the response value in percent. In the short run, the shock of the export tax is able to transmit to all the other prices. By using the model it is possible to predict this effect for 10 weeks taking into account not only the shock of the export tax but also the shocks of the international and domestic prices of $\mathrm{CPO}$ which potentially influence the short run dynamic of the prices. In the short run, the shock of the export tax of CPO will induce the increasing of the $\mathrm{CPO}$ domestic price at the beginning of the first week after which the CPO Indonesia price will sharply go down until the second week and it will steadily continue to decrease afterwards.
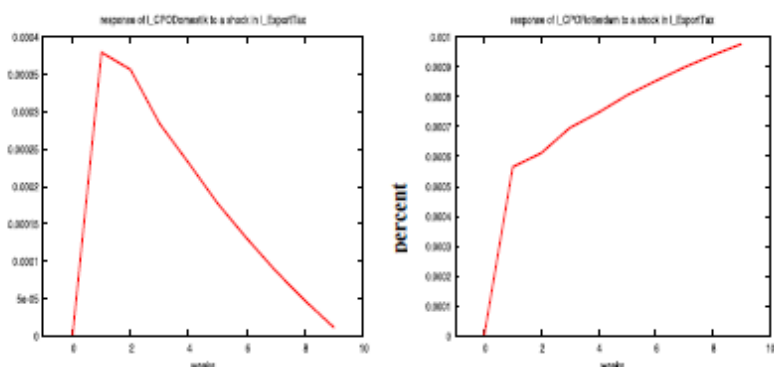

Fig. 2. Shock of export tax of CPO towards CPO prices

Whereas, in the case of the Rotterdam CPO price, the shock of the export tax will produce a different respond compared to the effect it has on the domestic CPO price. The Rotterdam CPO price will increase strongly within in the first week and will continue to grow afterwards.
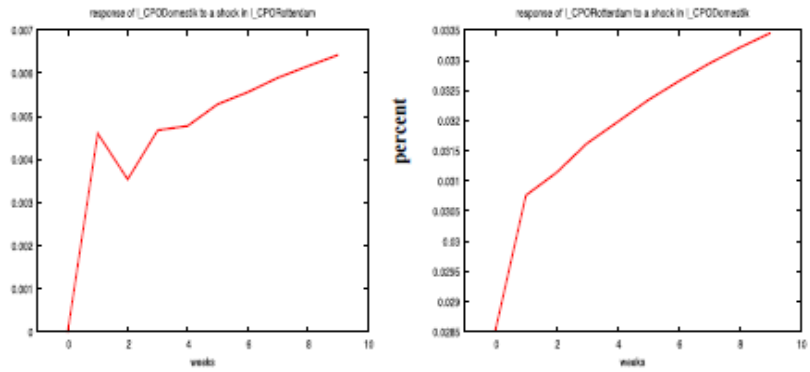

Fig. 3. Shock of CPO prices

Secondly, if there is a shock of the Rotterdam CPO price, the CPO Indonesia price will develop in a positive direction within the first week and in a negative direction within the second week followed by a positive development for the remaining weeks. On the other hand, a shock of the CPO Domestic price will increase the CPO international price during the whole period of 10 weeks.

\section{4) The Effects of Export Tax of CPO on Market Integration of $\mathrm{CPO}$ Commodity}

The implementation of the export tax is statistically significant, however the level of its effect does not have a very strong influence on the stability of the domestic CPO price. There are mainly three negative consequences of the implementation of the export tax on CPO product. The first one is reducing the opportunity for farmers and $\mathrm{CPO}$ producers to derive benefit from the increasing of the international CPO price because the export tax might keep the domestic price stable. The second consequence is the possible reduction of the welfare of farmers and producers of CPO (Susila 2004; K.P.E. Intan et al 2008, Obado et al 2009). As a third consequence, this policy could be disincentive for farmers to enhance the productivity of Fresh Fruit Bunch (FFB) as they might receive a lower price from the CPO producers. In other words, the long run impact of the export tax will consist in reducing the size of the palm oil plantations in Indonesia (Purba 2012). Thus, the export tax will downgrade the level of competitiveness of CPO Indonesia in the world market (Obado et al. (2009); Immanuel et al. (2016).

The next interesting point related to the output of the VECM estimation is the strong relationship between both prices of CPO in the long-term period. Despite being the biggest exporter of $\mathrm{CPO}$ product in the world, Indonesia does not have a robust power to control the price. In most parts of the observation period the domestic price of CPO followed the fluctuation of the world price so that it can be said that the global price of CPO led the dynamic price of $\mathrm{CPO}$ in the Indonesian market. This finding is in line with the previously mentioned studies e.g. Hafizah (2009); Purba (2012); Rifin (2014). Besides that, if it is quite easy for the prices to shift together, it means the information from the world market is quickly transferred to the domestic market of CPO or in other words the CPO market is efficient and close to perfect competition market.

As the result shows that palm oil stock will move to the domestic market, it is mean in the case of excess supply, when the price drops, local farmer or industries get no profit. Furthermore, government needs to find the way how to absorb the stock of farmer and manage the availability of stock conversely.

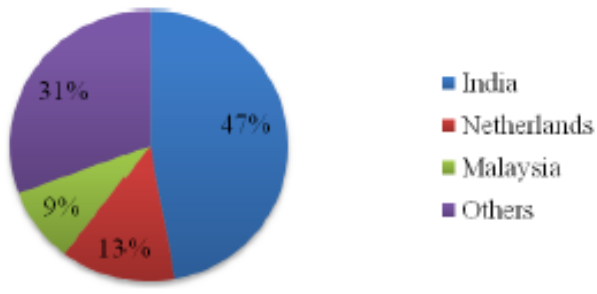

Source: Author's calculation based on UN COMTRADE (2017)

Fig. 4. Structure of Indonesia's CPO export destination

Based on Figure 4, the circumstance of the CPO Indonesia price being the price taker although the supply of CPO to the Netherlands mostly comes from Indonesia, makes it obviously clear that the market power of Rotterdam is much bigger than the one of the Indonesian market of CPO, enabling the Rotterdam market to control the price. In addition to this, it is plausible that the CPO producers in Indonesia tend to export into the world market due to the incentive being higher compared to supplying to the domestic market. Thereby, it is important for the government of Indonesia to cope with a shortage of supply of CPO product in the domestic market when the international price increases by switching the composition of 
volume export of palm oil products and encouraging the CPO producers to consider to export derivative products of palm oil i.e. RPO. Some scholars meet the result that the export tax successfully detracted the volume export of CPO and raised the volume of RPO (Purba 2012; Rifin 2014; Immanuel et al. 2016). It is possible to confirm that this finding is accordance with the implementing the export tax for reducing the volume export of $\mathrm{CPO}$ (Helpman and Krugman 1989).

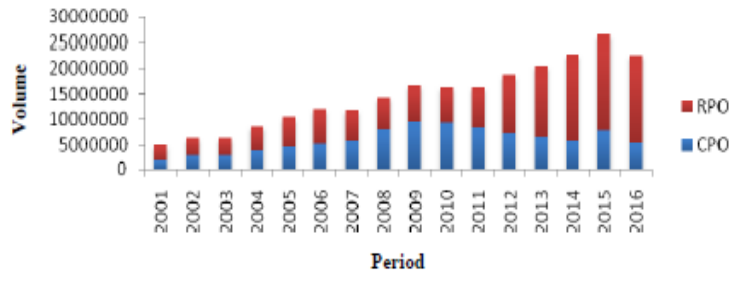

Source: Ministry of Trade (2017)

Fig. 5. Palm oil and its fraction (HS 15110) Indonesia export volume in 2001-2016 (Ton)

\section{CONCLUSIONS AND RECOMMENDATIONS}

\section{A. Conclusions}

1) The domestic $\mathrm{CPO}$ market of Indonesia is integrated with the international market. In the long run, both prices have a relationship or in other words the volatility price in the international CPO market will be transmitted to the domestic market in Indonesia.

2) In the long run, although the imposition of the export tax of $\mathrm{CPO}$ in Indonesia makes it possible to prevent the instability of the domestic price of $\mathrm{CPO}$, the level of influence is still small. The interference on the CPO market by the policy maker, in particular to reach the aim of stock availability of CPO in the domestic market, consisted in changing the composition of export, which is reflected by the growing share of derivative product of palm oil i.e. RPO in the export.

\section{B. Recommendations}

Based on the small value of the coeffient of the export tax, in the long run it can be said that the imposition of the export tax will give a minimum damage to the farmes and producers of CPO. In other words, the government of Indonesia might be better to continue this policy as it will generate several benefits such as a higher consumer surplus from cooking oil product and the additional fiscal revenue from export tax. This study finds that the transmission between the CPO world price and the Indonesia domestic price is not constant over the period since the result of the Chow test rejects the null of hypothesis of parameter constancy in VECM. In addition, some autocorrelation and heteroskedasticity problems keep occurring. Thus, it is suggested for further research to develop a model of price transmission which estimates the existence of structural change more precisely using the regime dependent model and other models.

\section{REFERENCES}

[1] J.D. Fadila, "Price cointegration and causality analysis between international price of crude oil, cpo, and soybeans with VECM model," [in Bahasa Indonesia]. [Master Thesis], Bogor: Graduate School of IPB, March 2014

[2] D. Gujarati, Basic econometric fourth edition. The Mac Graw-Hill Companies: Singapore, 2004

[3] D. Hafizah, "Study on Indonesian government policy on CPO trade using market integration approach," [in Bahasa Indonesia] Jurnal AGRISEP, pp. 10(2), September 2011.

[4] E. Helpman and P.R. Krugman. Trade policy and market structure. MIT Press: Cambridge, 1989.

[5] Immanuel, M. Khaliqi, and A. Amiruddin, "The effect of estate-crop fund on Indonesia's crude palm oil export competitiveness," Proceeding International Conference Strengthening Indonesia Agribusiness: Rural Development and Global Market Linkages. Bogor (ID), 25-26 April 2016.

[6] K.P.E. Intan, Widyastutik, A. Rifin, S. Hartoyo, and H. Daryanto, "The export tax policy of crude palm oil: the development and taxes mechanism," [in Bahasa Indonesia] Jurnal Agribisnis dan Ekonomi Pertanian, vol 2(1), June 2008.

[7] H. Khotimah, S. Von Cramon-Taubadel, Suharno, and R Nurmalina, "Vertical Market Integration Performance of Indonesian Rice Market Chain," Proceeding International Conference Strengthening Indonesia Agribusiness: Rural Development and Global Market Linkages. Bogor (ID), 25-26 April 2016.

[8] T. Kopp, Z. Alamsyah, R.S Fatricia, and B. Brümmer, "Have Indonesian Rubber Processors Formed a Cartel? Analysis of intertemporal marketing margin manipulation," Ecological and Socioeconomics Functions of Tropical Lowland Rainforest Transformation Systems (EFForTS) Discussion Paper Series, vol 3, January 2014.

[9] J. Obado, Y. Syaukat, and H. Siregar, "The Impacts Of Export Tax Policy On The Indonesian Crude Palm Oil Industry," Journal International Society For Southeast Asian Agricultural Sciences, vol. 15(2), pp. 107-119, November 2009.

[10] J.H.V. Purba, "The impact of export tax crude palm oil on cooking oil industri in Indonesia," [in Bahasa Indonesia]. [PhD Thesis], Bogor (ID): Graduate School of IPB, February 2012.

[11] A. Rachman, "Market Integration and Price Transmission on the CPO and cooking oil markets in Indonesia," [in Bahasa Indonesia]. [Master Thesis], Bogor (ID): Graduate School of IPB, August 2012.

[12] A. Rifin, "The effect of crude palm oil export tax on export and prices," ASEAN Journal of Economics, Management and Accounting, vol 2 (1\&2), pp. 82-95, November 2014.

[13]A. Sulistyanto and R. Akyuwen, "Factors affecting the performance of Indonesia's crude palm oil export," International Conference on Economics and Finance Research, vol. 4, 2011.

[14] W.R. Susila, "Impacts of cpo export tax on several aspects of Indonesian cpo industry,” Oil Palm Industry Economic Journal, 2004. 